\title{
Analisis Postur Kerja dengan Menggunakan REBA dan RULA di PT X
}

\section{Worker Posture Analysis Using REBA and RULA at PT X}

\author{
Vincent Tiogana, Natalia Hartono \\ Jurusan Teknik Industri, Universitas Pelita Harapan, Tangerang \\ E-mail: vincenttiogana@gmail.com,natalia.hartono@uph.edu
}

\begin{abstract}
Abstrak
PT. X merupakan pabrik yang memproduksi beragam produk kopi. Proses produksi pada perusahaan tersebut terdiri dari roasting, mixing, grinding, dan packing $(1,2,3,4)$. Perusahaan ini masih merupakan perusahaan padat karya. Pada pengamatan awal, terlihat pekerja memiliki posisi kerja yang kurang baik sehingga ada resiko bahaya muskuloskeletal, sehingga akan dilakukan pengambilan data dengan menggunakan wawancara dan kuesioner Cornell Musculoskeletal Discomfort Questionnaires (CMDQ). Resiko bahaya muskuloskeletal yang teramati ada pada beberapa area tubuh, seperti punggung bawah, betis, dan lainnya. Analisa postur tubuh dengan metode Rapid Entire Body Assessment (REBA) dan Rapid Upper Limb Assessment (RULA) digunakan pada penelitian ini. Metode REBA digunakan untuk analisa postur pada proses roasting, mixing, grinding, dan packing 4, sedangkan packing 1, 2, dan 3 menggunakan metode RULA. Pada hasil analisa REBA, postur yang paling berbahaya adalah pada stasiun 4 dengan nilai 9, sedangkan postur yang paling berbahaya pada analisa RULA adalah pada stasiun packing 1 dan 2 dengan nilai 6. Pemberian solusi perbaikan dilakukan terhadap stasiun yang dianggap berbahaya bagi pekerjanya, yakni stasiun roasting, mixing, grinding, packing 1, 2, dan 4. Solusi yang diberikan berbeda-beda tergantung pada kebutuhan, diantaranya adalah dengan mengubah metode kerja dan menggunakan troli yang dapat disesuaikan.
\end{abstract}

Kata Kunci: Cornell Musculoskeletal Discomfort Questionnaires (CMDQ), Gangguan Muskuloskeletal, Rapid Entire Body Assessment (REBA), Rapid Upper Limb Assessment (RULA)

\begin{abstract}
PT. $X$ is a factory that produces a variety of coffee products. The production process at the company consists of roasting, mixing, grinding, and packing (1,2,3,4). This company is still a labour-intensive company. At the initial observation, it appears that workers have bad posture for their work positions. Hence, there is a risk of musculoskeletal danger. The data collection will use interviews and Cornell Musculoskeletal Discomfort Questionnaires (CMDQ) questionnaires. Musculoskeletal Disorder problems are observed in several areas of the body, such as the lower back, calves, and others. Body posture analysis using Rapid Entire Body Assessment (REBA) dan Rapid Upper Limb Assessment (RULA) methods was used in this study. REBA method is used for posture analysis in the process of roasting, mixing, grinding, and packing 4, while packing 1, 2, and 3 use the RULA method. In the results of REBA analysis, the most dangerous posture is station 4 with a value of 9 , while the most hazardous posture on RULA analysis is at packing stations 1 and 2 with value 6. Solution for improvement was given for roasting, mixing, grinding, packing 1, 2 and 4. The solutions are varied depending on the needs, either changing the work method or using an adjustable trolley.
\end{abstract}

Keywords: Cornell Musculoskeletal Discomfort Questionnaires (CMDQ), Muskuloskeletal Disorder, Rapid Entire Body Assessment (REBA), Rapid Upper Limb Assessment (RULA) 


\section{Pendahuluan}

Industri manufaktur dengan skala kecil masih menggunakan tenaga kerja manusia dalam bekerja. Berdasarkan pengakuan dari sebagian pelaku industri manufaktur dengan skala kecil, manusia dianggap memerlukan biaya yang lebih rendah dibanding dengan penggunaan mesin otomasi. Selain dari segi biaya yang diperlukan, penggunaan tenaga kerja manusia dinilai bisa melakukan beberapa pekerjaan dengan lebih teliti dibanding dengan mesin yang memiliki tingkat ketelitian yang rendah atau mesin yang murah.

Para pelaku industri pada industri manufaktur tentu mengharapkan produksi bisa berjalan terusmenerus, sehingga bisa mencapai target produksi yang telah ditetapkan. Dengan harapan tersebut, mesin maupun tenaga kerja manusia harus bekerja dalam jangka waktu yang lama. Mesin bisa melakukan pekerjaan dalam waktu lama, karena mesin tidak bisa merasakan kelelahan layaknya manusia. Penggunaan tenaga kerja manusia dalam waktu yang lama harus didukung dengan metode kerja yang ideal dan stasiun kerja yang sesuai dengan postur tubuh pekerja, sehingga tidak terjadi cedera pada pekerja. Pekerja di negara berkembang dengan tenaga kerja murah, biasanya mengabaikan metode analisis postur padahal proses repetitif dan material handling manual merupakan problem utama di pabrik yang mengakibatkan musculosketal disorder (MSDs) karena proses repititif dan postur yang buruk (Singh, 2010).

Perancangan suatu metode kerja dan stasiun kerja harus mempertimbangkan postur tubuh dari pekerja. Metode kerja dan stasiun kerja yang dirancang harus membuat pekerja memiliki postur tubuh yang ergonomis saat melakukan pekerjaannya. Tanpa adanya postur tubuh ergonomis, bisa menyebabkan pekerja bekerja pada postur tubuh yang tidak alami. Pekerja sering kali melakukan suatu pekerjaan dalam jangka waktu yang lama. Melakukan suatu pekerjaan dalam jangka waktu yang lama tanpa didukung oleh postur tubuh yang alami bisa menyebabkan cedera pada pekerja, yaitu musculoskeletal disorders (MSDs). Musculoskeletal disorders merupakan cedera atau gangguan yang dapat mempengaruhi pergerakan tubuh manusia atau sistem muskuloskeletal, seperti otot, ligamen, dan lain-lain (Ergomics Plus, n.d.). Apabila pekerja mengalami cedera, bukan hanya pekerja yang dirugikan, tetapi juga pihak perusahaan bisa dirugikan, karena pekerja tidak bisa bekerja atau tidak maksimal dalam melakukan pekerjaannya. Pengukuran tingkat faktor resiko adalah alat pencegahan MSDs yang penting (Chiasson et.al, 20015). Pengukuran posisi operator juga merupakan hal penting karena mempengaruhi aktifitas produksi (Annisa, 2018).

PT. X adalah perusahaan manufaktur yang memproduksi kopi, kopi 3 in 1 , dan cappucino. Berdasarkan hasil observasi, pada PT. X ditemukan pekerja yang masih bekerja dengan metode yang tidak ideal atau tanpa dukungan stasiun kerja (meja atau kursi) yang ergonomis. Bekerja dalam waktu yang lama dengan keadaan tersebut bisa menyebabkan cedera pada pekerja, seperti MSDs. Pada perusahaan ini terdapat 4 stasiun kerja, yakni roasting, mixing, grinding, dan packing. Keempat stasiun kerja tersebut masih memiliki pekerja yang memiliki resiko cedera.

Tujuan penelitian ini adalah menganalisa postur tubuh pekerja pada masing-masing stasiun kerja dan merancang usulan perbaikan metode kerja atau stasiun kerja untuk meminimalkan resiko cedera pekerja saat bekerja. Pengumpulan data pada penelitian ini akan dilakukan dengan cara wawancara terhadap pekerja dan menggunakan kuesioner Cornell Musculoskeletal Discomfort Questionnaires (CMDQ) untuk mengetahui bagian tubuh pekerja yang tidak nyaman atau merasakan sakit. Pengolahan data dilakukan dengan cara menggunakan metode Rapid Entire Body Assessment (REBA) dan Rapid Upper Limb Assessment (RULA) untuk menilai postur tubuh pekerja saat melakukan pekerjaannya. REBA dan RULA digunakan untuk mengetahui tingkat bahaya muskuloskeletal dari postur kerja pekerja. Metode REBA lebih baik digunakan ketika menganalisa pekerjaan yang membutuhkan pergerakan dari seluruh bagian tubuh, sedangkan metode RULA lebih baik digunakan ketika pekerjaan tersebut mengharuskan pekerja diam pada suatu tempat tertentu, seperti pekerjaan mengetik. Penggunaan kedua metode ini karena perbedaan dalam kelebihan dari masing-masing metode. 


\section{Tinjauan Pustaka}

Musculoskeletal Disorders (MSDs) adalah masalah kesehatan yang berbahaya yang sering ditemui di lingkungan kerja. Menurut Ergonomics Plus, terdapat beberapa jenis MSDs, yaitu carpal tunnel syndrome, tendonitis, muscle/tendon strain, ligament prain, tension neck syndrome, digital neuritis, and DeQuervain's syndrome. Menurut Canadian Centre for Occupational Health and Safety (CCOHS), Work-Related Musculoskeletal Disorders (WMSDs) disebabkan oleh aktivitas pekerjaan yang sering dilakukan dan dilakukan dengan berulang, ataupun pekerjaan yang dilakukan dengan postur yang tidak alami (2014). WMSDs memiliki beberapa nama yang berbeda, yaitu repetitive motion injuries, repetitive strain injuries, cumulative trauma disorders, dan soft tissue disorders. Faktor penyebab WMSDS adalah penggunaan tenaga berlebihan, melakukan pekerjaan dalam jangka waktu yang lama, melakukan pekerjaan yang repetitif, bekerja dengan postur yang tidak alami, mempertahankan satu postur dalam waktu yang lama, getaran, faktor lingkungan, dan faktor psikososial (WHO, 2001). Hal yang perlu diperhatikan untuk meminimalkan gangguan MSDs adalah dengan keseimbangan antara bekerja dan istirahat, prinsip ergonomi, metode kerja, dan menghindari kecelakaan dan cedera. Cornell Musculoskeletal Discomfort Questionnaires (CMDQ) adalah kuesioner yang dirancang oleh Dr. Alan Hedge dan beberapa mahasiswa lulusan Ergonomi dari Cornell University pada tahun 1999 (Hedge,1999). Kuesioner ini dirancang untuk tujuan penyaringan pada suatu penelitian, bukan untuk mendiagnosa penyakit atau cedera. Terdapat 3 jenis kuesioner CMDQ, yakni kuesioner untuk pekerja pada posisi tetap, posisi duduk, dan untuk pekerja yang memiliki gejala pada tangan. Masing-masing kuesioner memiliki 3 kategori penilaian, yaitu frekuensi rasa sakit, ketidaknyamanan, dan tingkat gangguan terhadap pekerjaan.

REBA adalah metode sistematis yang mengevaluasi seluruh postur tubuh pekerja untuk mengidentifikasi resiko MSDs dan resiko lain yang berhubungan dengan pekerjaan (Ergonomics Plus,n,d.). Pertama kali diperkenalkan oleh Hignett dan McAtamney (Hignett et.al, 2000). Satu lembaran REBA digunakan untuk mengevaluasi postur tubuh, penggunaan tenaga, jenis pergerakan, pengulangan, dan pegangan (coupling). REBA dirancang agar mudah untuk digunakan sehingga tidak diperlukan keahlian yang tinggi ataupun peralatan yang mahal. Alat yang diperlukan hanya lembaran REBA dan alat tulis.

RULA adalah suatu metode untuk menganalisa ergonomi postur tubuh pada pekerjaan dengan penggunaan bagian tubuh atas. Analisa RULA dilakukan apabila terdapat laporan keluhan pada tubuh bagian atas yang disebabkan oleh postur tubuh yang tidak ergonomis. (McAtamney dan Corlett, 1993). Metode RULA mudah untuk digunakan, karena tidak membutuhkan peralatan khusus dalam pelaksanaannya. Beberapa faktor yang dilakukan analisa pada metode RULA adalah sebagai berikut posisi kerja pada keadaan statis, beban pekerjaan, jangka waktu pekerjaan, energi otot yang digunakan.

\section{Pembahasan}

Hal pertama yang dilakukan dalam penelitian ini adalah melakukan pengamatan di PT.X dengan observasi kondisi pabrik PT.X. Setelah melakukan observasi pada kondisi pabrik, selanjutnya dilakukan wawancara kepada pemilik hingga pekerja. Salah satu masalah yang dihadapi PT.X adalah terdapat beberapa stasiun kerja yang memiliki metode kerja atau fasilitas yang tidak ergonomis dengan tubuh pekerja. Oleh karena itu, terdapat beberapa pekerja yang mengeluh adanya rasa sakit pada beberapa bagian tubuh. Studi literatur yang dilakukan adalah pencarian teori mengenai ergonomi, postur kerja, musculoskeletal disorders (MSD), Rapid Entire Body Assessment (REBA) dan Rapid Upper Limb Assessment (RULA). 
Pengumpulan data dengan wawancara dan kuesioner yang kemudian diolah dengan tahapan sebagai berikut:

1. Pengolahan data CMDQ

Pengolahan data pada kuesioner CMDQ dilakukan untuk mengetahui bagian tubuh yang paling sering mengalami rasa sakit atau nyeri, sehingga bisa diketahui posisi kerja yang paling berbahaya bagi pekerja. Pengolahan data kuesioner CMDQ dilakukan berdasarkan bobot nilai yang sudah ditentukan, yakni sebagai berikut.

a. Frekuensi

1. Tidak pernah $=0$

2. $1-2$ kali seminggu $=1,5$

3. $3-4$ kali seminggu $=3,5$

4. 1 kali setiap hari $=5$

5. Beberapa kali setiap hari $=10$

b. Ketidaknyamanan

1. Sedikit tidak nyaman $=1$

2. Agak tidak nyaman $=2$

3. Sangat tidak nyaman $=3$

c. Kemampuan bekerja

1. Tidak sama sekali $=1$

2. Sedikit terganggu $=2$

3. Sangat/sungguh menganggu $=3$

Tiga jenis data yang diperoleh kemudian akan dilakukan perkalian, sehingga didapatkan nilai CMDQ. Nilai CMDQ yang paling tinggi menunjukkan bagian tubuh tersebut paling sering mengalami rasa sakit atau nyeri.

2. Pengolahan data REBA dan RULA

Pengolahan data dengan metode REBA dilakukan pada stasiun kerja roasting, grinding, mixing, packing 4, sedangkan pengolahan dengan metode RULA dilakukan pada stasiun kerja packing 1, 2, dan 3. Pemilihan penggunaan metode REBA ketika stasiun kerja tersebut membutuhkan pergerakan dari seluruh tubuh sedangkan metode RULA digunakan pada stasiun kerja yang pekerjanya diam di stasiun kerjanya. Postur tubuh yang akan dianalisa adalah postur tubuh yang memungkinkan untuk menyebabkan rasa sakit sesuai dengan kuesioner CMDQ atau postur yang dilakukan dalam jangka waktu paling lama.

Data-data yang sudah diolah, selanjutnya akan dianalisis. Analisis dilakukan pada data kuesioner CMDQ, analisis postur tubuh dengan metode REBA dan RULA. Berdasarkan hasil pengolahan data dengan metode REBA dan RULA, bisa diketahui tingkat bahaya suatu postur kerja. Setelah mengetahui tingkat bahaya postur kerja dari setiap stasiun kerja, selanjutnya akan dilakukan usulan perbaikan yang bisa mengurangi atau menghilangkan bahaya postur kerja terhadap tubuh pekerja.

Stasiun kerja pada PT. X terdiri dari roasting, mixing, grinding, dan packing (1, 2, 3, dan 4). Pada proses roasting, pekerja akan mengambil sekarung biji kopi mentah kemudian menariknya ke stasiun roasting dan memasukkannya ke dalam suatu tempat yang terdapat pada mesin roasting. Apabila proses roasting sudah selesai, biji kopi akan dimasukkan lagi ke dalam karung dan pekerja akan memindahkannya ke stasiun mixing atau ke tempat penyimpanan apabila proses mixing tidak dilakukan di hari yang sama. Pada proses mixing produk kopi, pekerja akan memindahkan biji kopi dari tempat penyimpanan biji kopi ke stasiun kerja mixing kemudian menimbang biji kopi yang terdapat di dalam karung kemudian mengangkat karung-karung tersebut ke atas palet yang akan diangkat dengan menggunakan forklift agar pekerja bisa menuangkan biji kopi tersebut ke dalam mesin mixing. Pada proses mixing produk khusus, pekerja akan menimbang bahan-bahan yang diperlukan terlebih dahulu yang kemudian akan diangkat ke suatu kereta dorong untuk memindahkannya dari ruang bahan baku ke stasiun kerja mixing yang pada akhirnya akan dimasukkan ke dalam mesin mixing seperti pada proses mixing produk kopi. Setelah proses mixing 
selesai dilakukan, pekerja perlu membersihkan bagian dalam dari mesin tersebut untuk mencegah terjadinya pencampuran dengan produk lain. Pembersihan dilakukan dengan menggunakan bantuan kuas dengan panjang $18 \mathrm{~cm}$. Pada proses grinding, pekerja akan memindahkan karung biji kopi dari stasiun mixing dengan menggunakan gerobak dorong. Pekerja kemudian akan memulai proses grinding dengan cara memasukkan biji kopi ke dalam corong dan memposisikan ember di bawahnya untuk menampung kopi yang sudah dalam bentuk bubuk yang pada akhirnya akan diangkut ke stasiun packing dengan cara diangkat. Pada proses packing produk kopi, masingmasing pekerja memiliki tugas masing-masing. Pekerja pertama akan mengambil plastik bungkusan dan memasukkan bubuk kopi ke dalamnya dan kemudian memberikannya ke stasiun selanjutnya. Pekerja kedua akan mengambil bungkusan tersebut dan menimbangnya kemudian diberikan kepada stasiun selanjutnya. Pekerja ketiga akan mengambil bungkusan bubuk kopi yang sudah ditimbang dan menutup bungkusan dengan menggunakan bantuan mesin sealer. Cara pekerja menutup bungkusan adalah memposisikan bungkusan pada mesin sealer dan menginjak pedal yang terdapat pada mesin tersebut. Bungkusan bubuk kopi yang sudah ditutup akan dijatuhkan ke keranjang yang terletak di sebelahnya. Pekerja keempat akan mengambil bungkusan bubuk kopi dan menyusun bungkusan tersebut ke dalam sebuah kotak kardus yang kemudian akan tutup dengan selotip dan disusun dengan cara ditumpuk. Pada proses packing produk khusus, pekerja melakukan pekerjaan yang sama dengan pada saat packing produk kopi.

Wawancara dilakukan pada tujuh orang yang bekerja di lantai produksi. Pemilihan 7 orang sesuai dengan jumlah yang diberikan oleh pihak perusahaan. Salah satu pekerja (L2) yang dijadikan narasumber baru bekerja selama 2 hari, sehingga data pekerja tersebut tidak dimasukkan ke dalam pengolahan. Berikut adalah tabel ringkasan identitas dari narasumber wawancara yang telah dilakukan.

Tabel 1. Identitas Narasumber

\begin{tabular}{|c|c|c|c|c|c|}
\hline No & Nama & Gender & Tinggi badan $(\mathrm{cm})$ & Umur (tahun) & Stasiun Kerja \\
\hline 1 & L1 & Laki-laki & 160 & 59 & $\begin{array}{c}\text { Grinding \& } \\
\text { operator mesin } \\
\text { roasting }\end{array}$ \\
\hline 2 & L3 & Laki-laki & 158 & 21 & $\begin{array}{c}\text { Roasting \& } \\
\text { Mixing }\end{array}$ \\
\hline 3 & P1 & Perempuan & 162 & 52 & Packing 1 \\
\hline 4 & P2 & Perempuan & 150 & 47 & Packing 2 \\
\hline 5 & P3 & Perempuan & 155 & 43 & Packing 3 \\
\hline 6 & P4 & Perempuan & 150 & 47 & Packing 4 \\
\hline
\end{tabular}

Keterangan:

- Packing $1=$ memasukkan kopi ke dalam bungkusan plastik

- Packing $2=$ menimbang kopi

- Packing $3=$ menutup bungkusan kopi dengan menggunakan mesin sealing

- Packing $4=$ menyusun bungkusan kopi ke dalam kotak kardus

Enam narasumber terdiri dari dua laki-laki yang bekerja dalam posisi berdiri, tiga perempuan yang bekerja dalam posisi duduk, dan satu perempuan yang bekerja dalam posisi berdiri. Berdasarkan keterangan dari narasumber, para pekerja di PT. X memiliki beberapa peralatan yang wajib digunakan, yakni masker, topi, dan sarung tangan. Peralatan-peralatan tersebut tidak melindungi para pekerja selama bekerja, melainkan untuk menjaga tingkat kebersihan produk kopi yang diproduksi. 
FREKUENSI PEKERJA BERISTIRAHAT

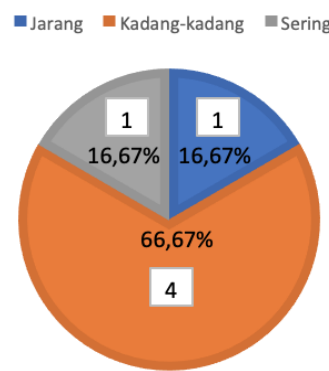

Gambar 1. Frekuensi Pekerja Beristirahat
FREKUENSI PEKERJA MELAKUKAN PEREGANGAN

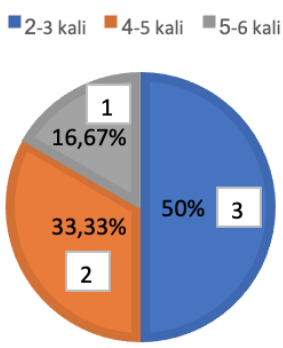

Gambar 2. Frekuensi Pekerja Melakukan Peregangan

Para pekerja memiliki jawaban yang berbeda-beda mengenai istirahat yang dilakukan selama bekerja, satu orang menjawab jarang beristirahat, empat orang menjawab kadang-kadang berisitirahat, dan satu orang menjawab sering beristirahat. Narasumber yang menjawab sering beristirahat adalah P1 yang merupakan pekerja perempuan yang sudah cukup berumur, yakni 52 tahun. Mengenai frekuensi peregangan tubuh ketika bekerja, tiga orang melakukan sebanyak 2-3 kali, dua orang melakukan peregangan sebanyak 4-5 kali, dan satu orang melakukan peregangan sebanyak 5-6 kali. Narasumber yang melakukan peregangan 5-6 kali ketika bekerja adalah L3 yang merupakan pekerja laki-laki yang berusia 21 tahun. Gambar 1 dan 2 merupakan ringkasan dari frekuensi istirahat dan peregangan pekerja.

Para pekerja yang bekerja dalam posisi duduk mengatakan bahwa mereka harus berdiri selama 5-6 jam dalam satu hari kerja, begitu pula dengan para pekerja yang bekerja dalam posisi berdiri. Satu orang pekerja dalam posisi duduk mengatakan bahwa kursi yang disediakan oleh pihak perusahaan nyaman untuk digunakan, sedangkan dua lainnya mengatakan bahwa kursi tersebut tidak nyaman untuk digunakan. Ketidaknyamanan tersebut dikarenakan kursi tersebut terbuat dari bahan plastik, dengan penggunaan dalam jangka waktu yang lama, kursi tersebut akan terasa panas. Tiga orang pekerja dalam posisi berdiri mengatakan bahwa pihak perusahaan menyediakan kursi yang bisa digunakan ketika mereka hendak beristirahat, namun sebagian memilih untuk duduk di lantai.

Enam pekerja tersebut merasakan ketidaknyamanan yang berbeda-beda selama bekerja. Berikut merupakan ringkasan dari ketidaknyamanan yang dirasakan oleh pekerja.

Tabel 2. Ketidaknyaman Pekerja

\begin{tabular}{|c|c|c|}
\hline No & Nama & Ketidaknyamanan yang dirasakan \\
\hline 1 & L1 & Punggung dan betis sakit, panas \\
\hline 2 & L3 & Lengan, punggung dan betis sakit \\
\hline 3 & P1 & Punggung sakit, panas \\
\hline 4 & P2 & Paha dan betis sakit, panas \\
\hline 5 & P3 & Punggung sakit \\
\hline 6 & P4 & Punggung dan betis sakit, panas \\
\hline
\end{tabular}

Berdasarkan pengakuan Bapak L1, rasa sakit atau nyeri yang dirasakan dikarenakan oleh beliau harus berdiri dalam jangka waktu yang sangat lama ketika bekerja. Bapak L3 mengatakan bahwa rasa sakit atau nyeri yang beliau rasakan dikarenakan beliau harus mengangkat beban yang sangat berat dan harus membersihkan mesin mixing. Beban yang dimaksud seperti mengangkat bahanbahan yang digunakan dalam mesin mixing. Salah satu bahan yang membebankan beliau adalah gula dengan berat $50 \mathrm{~kg}$. Beliau menambahkan bahwa beberapa rekan kerja beliau memilih untuk berhenti bekerja karena tidak sanggup untuk mengangkat beban yang terlalu berat. Beliau juga mengatakan bahwa selain mengangkat beban, membersihkan mesin mixing merupakan pekerjaan yang sangat melelahkan. P1 mengatakan bahwa punggung beliau sakit ketika bekerja dalam waktu yang lama, sehingga ketika beliau merasa sakit, beliau akan meminta rekannya untuk bertukar 
posisi kerja. Ibu P2 mengatakan bahwa rasa sakit atau nyeri yang beliau rasakan disebabkan oleh posisi duduk pada kursi dalam waktu yang lama. Ibu P3 memiliki jawaban yang mirip dengan Ibu P1. Ibu P4 mengatakan bahwa beliau mengalami sakit pada punggung dan betis dan merasa tidak nyaman karena panasnya tempat kerja.

Enam pekerja tersebut mengakui bahwa mereka berolahraga secara rutin di luar jam kerja. Berikut merupakan tabel ringkasan olahraga yang secara rutin dilakukan oleh para pekerja tersebut.

Tabel 3. Rutinitas Olahraga Pekerja

\begin{tabular}{|c|c|c|}
\hline No & Nama & Olahraga yang dilakukan \\
\hline 1 & L1 & Jalan pagi \\
\hline 2 & L3 & Sepakbola \\
\hline 3 & P1 & Senam \\
\hline 4 & P2 & Lari pagi \\
\hline 5 & P3 & Senam \\
\hline 6 & P4 & Senam \\
\hline
\end{tabular}

Berdasarkan hasil kuesioner CMDQ, setiap pekerja mengalami rasa sakit pada bagian tubuh yang berbeda-beda. Pekerja roasting dan mixing memiliki nilai CMDQ yang relatif tinggi pada bagian tubuh leher, punggung atas, punggung bawah, lutut, dan betis. Pekerja grinding memiliki nilai CMDQ yang relatif tinggi pada bagian tubuh punggung bawah dan betis. Pekerja packing 1 memiliki nilai CMDQ yang relatif tinggi pada bagian tubuh punggung atas dan punggung bawah. Pekerja packing 2 memiliki nilai CMDQ yang relatif tinggi pada bagian tubuh pinggul/bokong, paha, dan kaki bagian bawah. Pekerja packing 3 memiliki nilai CMDQ yang relatif tinggi pada bagian tubuh punggung bawah. Pekerja packing 4 memiliki nilai CMDQ yang relatif tinggi pada bagian tubuh punggung bawah, lutut, dan betis.

Berikut adalah pengolahan data dengan menggunakan metode REBA:

1. Roasting

Berdasarkan hasil CMDQ, pekerja ini memiliki keluhan rasa sakit di bagian leher, punggung atas, punggung bawah, lutut, dan betis. Pekerja ini bekerja pada 2 stasiun, sehingga keluhan rasa sakit bisa berasal dari 2 stasiun kerja. Keluhan rasa sakit yang diduga diakibatkan oleh proses roasting adalah punggung atas, punggung bawah, lutut, dan betis yang disebabkan oleh proses penarikan karung biji kopi mentah. Hal itu dikarenakan proses penarikan biji kopi mentah yang berat membutuhkan tenaga dari kaki, sehingga lutut dan betis menjadi sakit dan pegangan yang kurang ergonomis membuat pekerja harus membungkuk agar bisa mencapainya, sehingga punggung bagian atas dan bawah menjadi sakit. Proses penuangan biji kopi ke mesin roasting dilakukan oleh dua orang pekerja dan posisi normal karena itu tidak dilakukan pengukuran pada saat menuang ke mesin. 

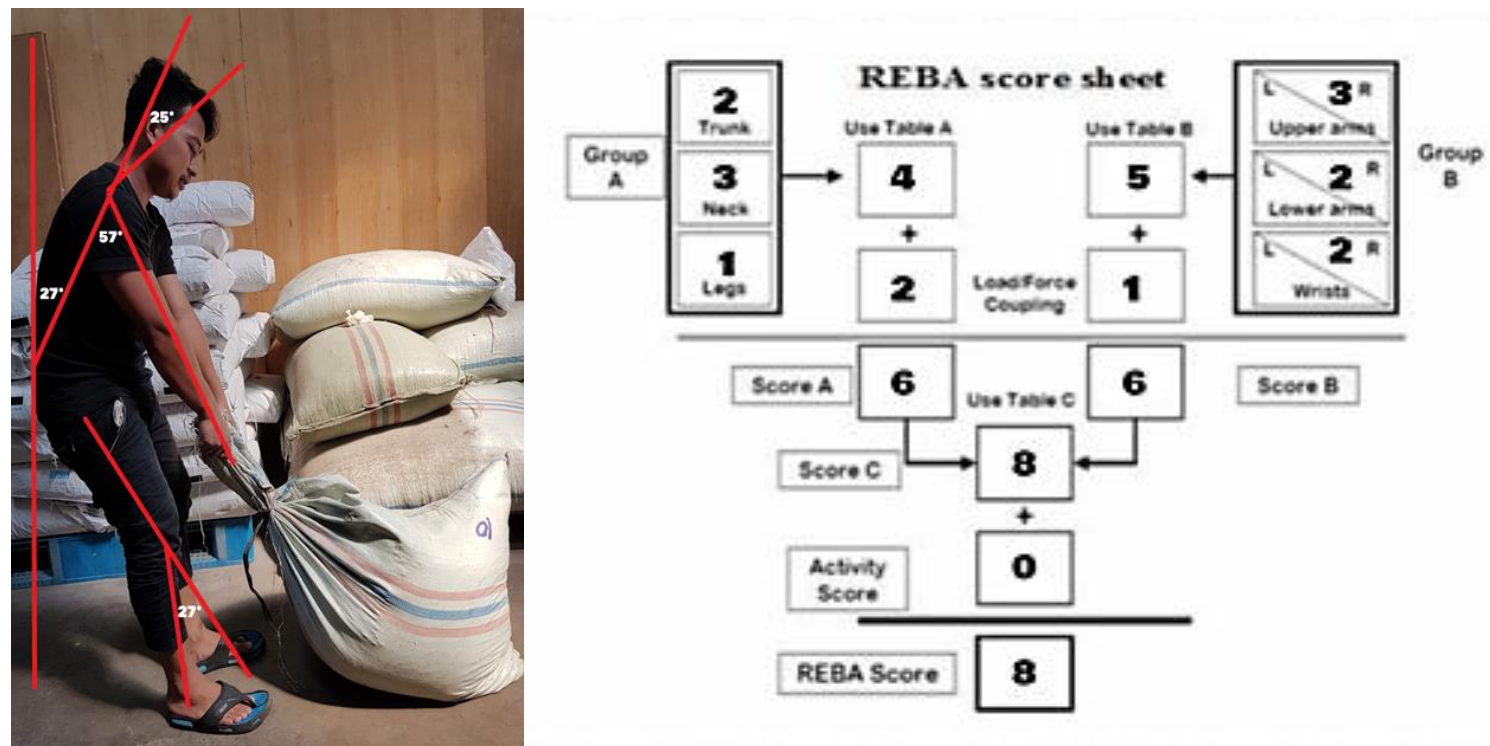

Gambar 3. Analisa Postur dan REBA score sheet Pekerja Roasting

Berdasarkan analisa REBA pada postur pekerja roasting yang telah dilakukan, postur pekerja tersebut menghasilkan nilai 8. Nilai tersebut menunjukkan bahwa postur tersebut tergolong dalam kategori resiko bahaya yang tinggi, langkah yang harus dilakukan adalah investigasi dan perubahan harus diimplementasikan. Posisi pegangan yang terlalu rendah menyebabkan pekerja harus membungkukkan badan dan leher serta lengan atas pekerja membentuk sudut yang relatif besar, sehingga perbaikan yang dibutuhkan adalah posisi pegangan yang lebih tinggi agar mengurangi resiko bahaya. Beban yang dihadapi pekerja relatif besar, sehingga dianjurkan agar mengurangi beban tersebut. Selain posisi pegangan dan beban yang dihadapi pekerja, bentuk pegangan juga perlu diperhatikan agar pekerja membentuk sudut pergelangan tangan yang ideal. Solusi perbaikan yang dianjurkan pada stasiun roasting adalah menggunakan troli adjustable (Harga \pm Rp 5 juta).

Berdasarkan analisis REBA yang dilakukan pada stasiun ini, pekerja memiliki beberapa postur tubuh yang tidak ideal. Hal itu disebabkan oleh posisi pegangan yang terlalu rendah, bentuk pegangan yang tidak ideal, dan beban yang terlalu besar. Pengunaan troli adjustable bisa meminimalkan resiko cedera muskuloskeletal yang dihadapi pekerja. Dengan adanya alat bantu tersebut, pekerja hanya perlu memindahkan karung biji kopi mentah ke troli tersebut dan menuangkan biji kopi mentah secara langsung ke corong pada mesin roasting tanpa perlu mengangkatnya dari lantai lagi. Proses pemindahan karung biji kopi mentah ke troli tidak perlu menggunakan tenaga yang besar. Pekerja hanya perlu menyesuaikan ketinggian troli dengan ketinggian karung biji kopi mentah yang sedang ditumpuk. Setelah kedua barang tersebut memiliki ketinggian yang sama, pekerja bisa langsung memindahkannya. Pada proses penuangan biji kopi mentah, biasanya pekerja perlu mengangkat karung tersebut hingga sesuai dengan ketinggian corong mesin roasting lalu menuangkannya. Dengan adanya alat bantu tersebut, pekerja hanya perlu menyesuaikan ketinggian troli dan langsung menuangkannya. Proses penarikan juga hanya membutuhkan tenaga yang kecil. Walaupun beban yang ditarik tetap sama, yaitu sebesar $35 \mathrm{~kg}$, namun dengan adanya roda pada troli, bisa meminimalkan tenaga yang perlu digunakan pekerja.

\section{Mixing}

Berdasarkan hasil CMDQ, pekerja ini memiliki keluhan rasa sakit di bagian leher, punggung atas, punggung bawah, lutut, dan betis. Seperti yang sudah disebut sebelumnya, pekerja ini bekerja pada stasiun roasting dan mixing. Keluhan rasa sakit adalah di leher, punggung bawah, lutut, dan betis yang disebabkan oleh proses pembersihan mesin mixing. Hal itu dikarenakan proses pembersihan mesin mixing, pekerja susah menjangkau bagian yang dalam $(100 \mathrm{~cm})$, sehingga punggung bawah, lutut, dan betis merasakan rasa sakit karena harus berdiri dengan 
posisi jinjit agar bisa menjangkaunya. Karena bagian dalam mesin susah dijangkau, pekerja harus memasukkan kepalanya agar bisa melihat dan menjangkau bagian dalam, sehingga leher pekerja menjadi sakit. Postur kerja yang akan dianalisa adalah pada saat pekerja sedang membersihkan bagian dalam mesin, karena postur tersebut dinilai paling berbahaya bagi pekerja. Proses persiapan dari stasiun roasting ke mixing menggunakan bantuan forklift saat menuang oleh dua orang dan posisi normal, sehingga pengukuran di stasiun ini saat pembersihan mesin.
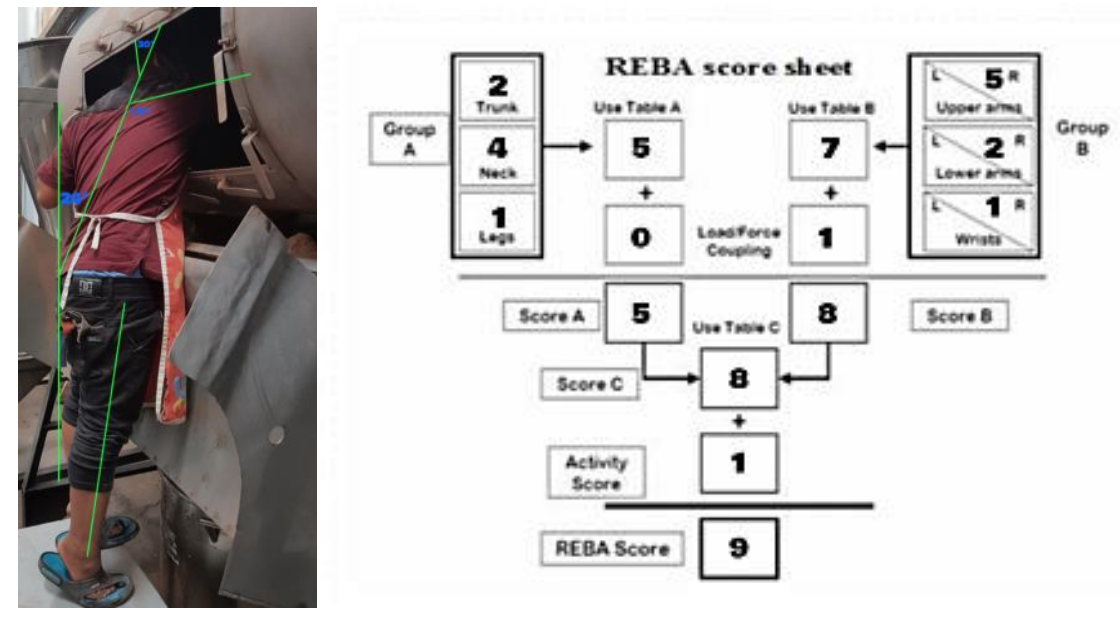

Gambar 4. Analisa Postur dan REBA score sheet Pekerja Mixing

Berdasarkan analisa REBA pada postur pekerja mixing yang telah dilakukan, postur pekerja tersebut menghasilkan nilai 9. Nilai tersebut menunjukkan bahwa postur tersebut tergolong dalam kategori resiko bahaya yang tinggi, langkah yang harus dilakukan adalah investigasi dan perubahan harus diimplementasikan. Mesin mixing memiliki kedalaman yang susah dicapai oleh pekerja, yakni $80 \mathrm{~cm}$. Hal itu menyebabkan ketika pekerja berusaha untuk membersihkan bagian paling dalam mesin, pekerja harus memasukkan kepalanya dan berdiri dengan posisi jinjit agar bisa meraihnya. Selain itu, postur lengan pekerja juga menjadi tidak ideal karena bahu membentuk sudut yang besar dengan posisi terangkat. Hal yang perlu dilakukan untuk mengurangi resiko bahaya cedera muskuloskeletal adalah menambah ukuran kuas yang digunakan oleh pekerja.

Solusi perbaikan yang dianjurkan pada stasiun mixing adalah menggunakan kuas yang lebih panjang. Mesin mixing, memiliki kedalaman yang susah dicapai oleh pekerja. Panjang kuas yang saat ini digunakan adalah $18 \mathrm{~cm}$. Dengan menggunakan kuas tersebut, pekerja harus memasukkan kepalanya ke dalam mesin, mengangkat bahu, dan berdiri dengan posisi jinjit. Apabila kuas yang digunakan digantikan dengan kuas yang memiliki panjang $30 \mathrm{~cm}$, maka pekerja tidak perlu bersusah payah untuk mencapai bagian paling dalam dari mesin tersebut lagi, sehingga bisa meminimalkan beberapa resiko bahaya muskuloskeletal pada pekerja.

\section{Grinding}

Berdasarkan hasil CMDQ, pekerja ini memiliki keluhan rasa sakit di punggung bawah dan betis. Kedua rasa sakit tersebut dikarenakan oleh pekerjaan pengambilan biji kopi. Pekerja harus mengambil biji kopi dalam posisi yang kurang ergonomis, sehingga bisa menyebabkan rasa sakit pada punggung bawah dan pekerja harus berdiri selama proses grinding berlangsung, sehingga bisa menyebabkan rasa sakit pada bagian betis. 

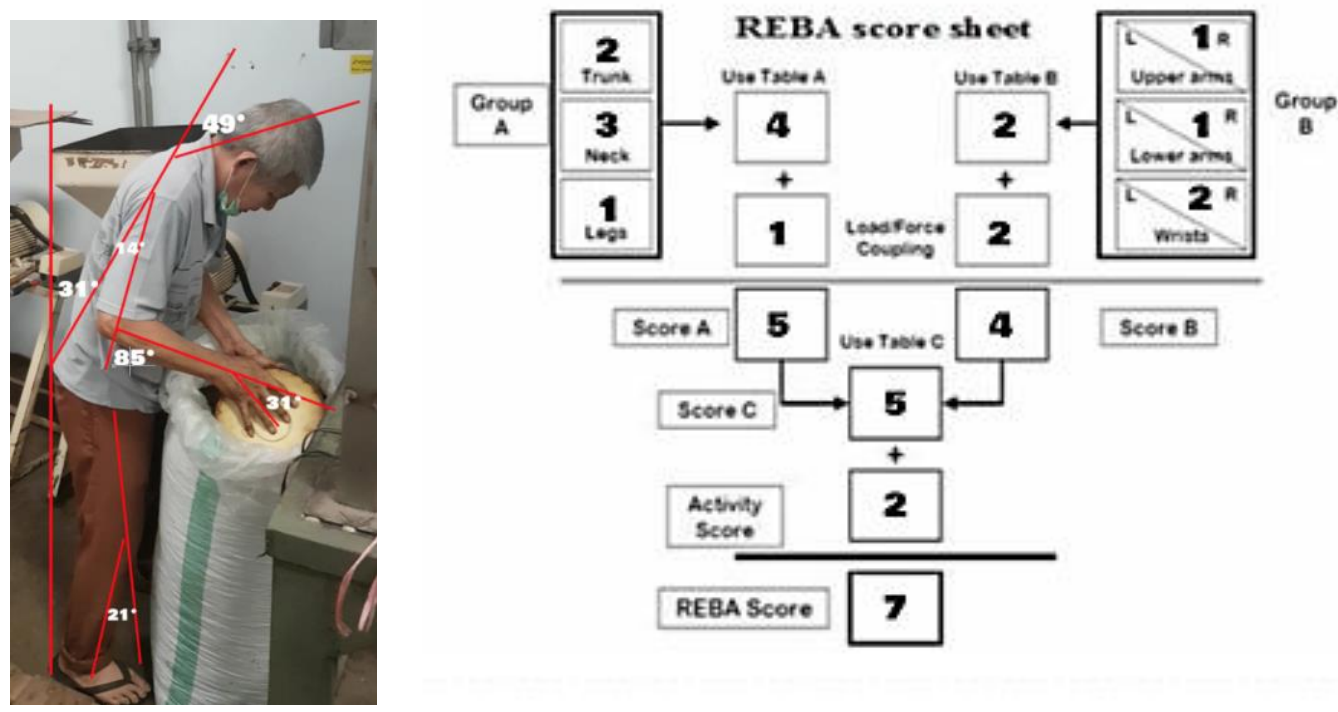

Gambar 5. Analisa Postur dan REBA score sheet Pekerja Grinding

Berdasarkan analisa REBA pada postur pekerja grinding yang telah dilakukan, postur pekerja tersebut menghasilkan nilai 7. Nilai tersebut menunjukkan bahwa postur tersebut tergolong dalam kategori resiko sedang, langkah yang harus dilakukan adalah investigasi lanjutan dan implementasikan harus dilakukan secepatnya. Karung biji kopi memiliki posisi yang cukup rendah yang menyebabkan pekerja tidak membentuk postur tubuh yang ideal. Hal ini bisa menyebabkan cedera muskuloskeletal pada leher dan badan pekerja, sehingga karung biji kopi dianjurkan untuk diletakkan pada posisi yang lebih tinggi untuk memudahkan pekerja untuk mengambil biji kopi. Selain posisi karung biji kopi, hal yang juga perlu diperhatikan adalah pegangan pada ember. Ember tersebut tidak memiliki pegangan yang ideal sehingga bisa mencederai pergelangan tangan pekerja.

Solusi perbaikan yang dianjurkan pada stasiun grinding adalah menggunakan bantuan troli adjustable, membuat mekanisme penyedotan biji kopi, dan memberikan kursi pada stasiun kerja ini. Pada proses grinding, pekerja juga perlu memindahkan karung biji kopi. Apabila proses mixing dilakukan pada hari yang sama, maka pekerja hanya perlu memindahkannya dari stasiun mixing. Apabila proses mixing tidak dilakukan di hari yang sama, maka pekerja perlu memindahkan karung biji kopi dari tempat penyimpanan. Dengan adanya troli adjustable, pekerja bisa lebih mudah memindahkannya dan juga mempermudah proses pengambilan biji kopi yang akan dituangkan ke corong mesin grinding.

Berdasarkan analisis REBA yang telah dilakukan, posisi karung biji kopi terlalu rendah dibandingkan dengan tinggi pekerja, sehingga pekerja perlu membungkukkan badan dan leher untuk mengambil biji kopi. Dengan menggunakan troli adjustable, pekerja bisa menyesuaikan ketinggian karung biji kopi agar sesuai dengan postur tubuh yang ideal.

Selain penggunaan tenaga manusia untuk menuangkan biji kopi ke dalam corong mesin grinding, bisa juga menggunakan mekanisme penyedotan. Mekanisme penyedotan yang dimaksud seperti pada mesin roasting, dimana pekerja hanya perlu menuangkan biji kopi ke dalam corong dan akan mesin akan melakukan penyedotan secara langsung. Dengan adanya mekanisme penyedotan pada mesin grinding, pekerja hanya perlu menuang biji kopi ke dalam corong dan menunggu proses grinding selesai agar bisa dipindahkan ke stasiun packing. Berdasarkan hasil wawancara yang dilakukan dengan pekerja stasiun ini, pekerja mengakui bahwa pekerja mengalami rasa sakit pada bagian punggung bawah dan betis karena harus berdiri dalam waktu yang lama di depan mesin. Dengan adanya mekanisme penyedotan dan penambahan kursi, pekerja bisa menunggu proses grinding dengan posisi duduk. 


\section{Packing 4}

Berdasarkan hasil CMDQ, pekerja ini memiliki keluhan rasa sakit di punggung bawah, lutut, dan betis. Keluhan rasa sakit tersebut dikarenakan oleh pekerjaan penyusunan kopi kemasan ke dalam kotak kardus. Pekerja harus menyusun kopi dalam posisi sangat membungkuk, sehingga bisa menyebabkan rasa sakit pada punggung bawah dan dengan posisi berdiri menambah rasa sakit pada bagian lutut dan betis.
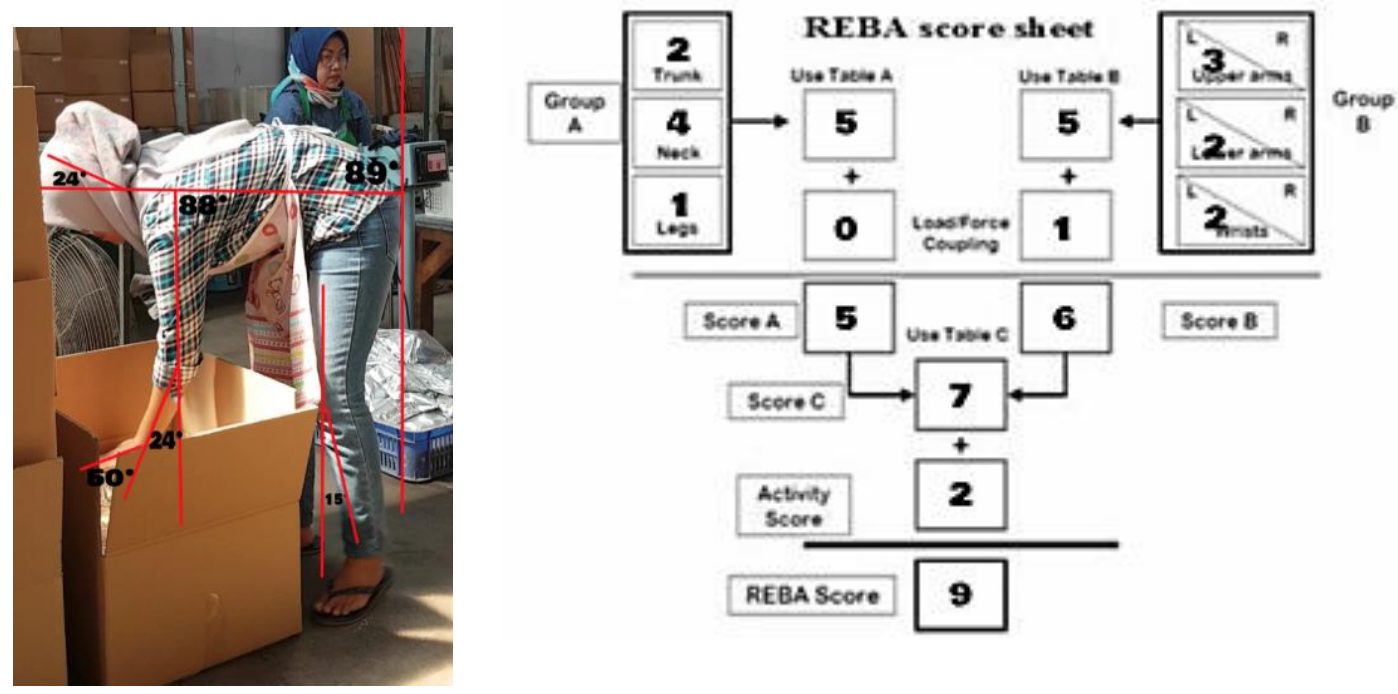

Gambar 6. Analisa Postur dan REBA score sheet Pekerja Packing 4

Berdasarkan analisa REBA pada postur pekerja packing 4 yang telah dilakukan, postur pekerja tersebut menghasilkan nilai 9. Nilai tersebut menunjukkan bahwa postur tersebut tergolong dalam kategori resiko bahaya yang tinggi, langkah yang harus dilakukan adalah investigasi dan perubahan harus diimplementasikan. Pada stasiun ini, pekerja seharusnya tidak berdiri pada saat melakukan pekerjaannya. Karena pekerja berdiri membungkuk, bisa menyebabkan cedera muskuloskeletal pada bagian tubuh badan dan leher menjadi menengadah. Selain itu, pekerja juga membentuk sudut lengan atas, lengan bawah, dan pergelangan tangan yang besar. Hal yang perlu dilakukan adalah mengurangi jarak antara badan pekerja dan kotak kardus, agar pekerja bisa bekerja dalam posisi yang ideal.

Solusi perbaikan yang dianjurkan pada stasiun packing 4 adalah mengubah metode kerja. Pada stasiun ini, pekerja bekerja dengan posisi yang membungkuk yang berpotensi untuk menimbulkan cedera muskuloskeletal yang serius pada punggung pekerja. Pekerja harus mengganti metode kerja yang saat ini digunakan. Pekerja sebaiknya bekerja dalam posisi duduk, sehingga pekerja tidak perlu membungkukkan badannya. Setiap satu kotak yang sudah terisi, pekerja memindahkan kotak tersebut ke palet yang sudah disediakan dan mengambil kotak kardus yang baru untuk diisi. 

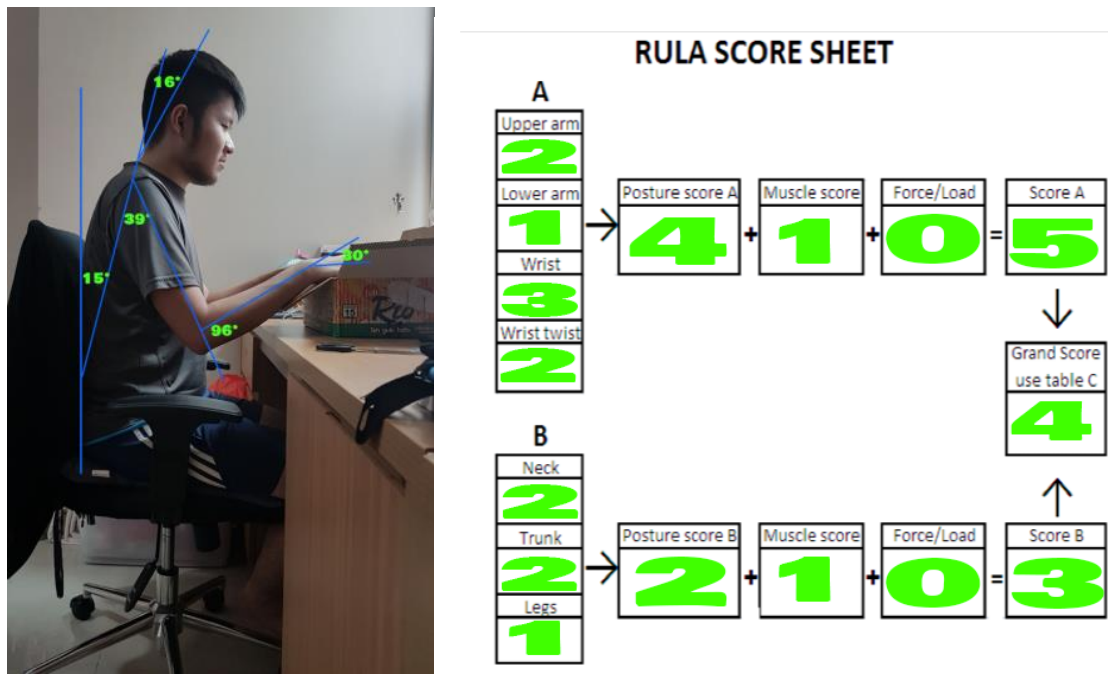

Gambar 7. Metode Kerja dan score sheet Modifikasi

Perubahan metode kerja mengurangi tingkat resiko bahaya pada pekerja. Postur kerja yang saat ini digunakan menghasilkan nilai REBA sebesar 9, sedangkan postur kerja dari solusi perbaikan yang ditawarkan menghasilkan nilai RULA sebesar 4. Nilai tersebut menunjukkan bahwa postur tersebut memiliki resiko bahaya yang lebih kecil dibandingkan dengan postur sebelumnya.

Berikut adalah pengolahan data dengan menggunakan metode RULA:

1. Packing 1

Berdasarkan hasil CMDQ, pekerja ini memiliki keluhan rasa sakit di punggung atas dan punggung bawah. Pekerja ini memiliki pekerjaan dengan postur yang relatif sama setiap saatnya, sehingga postur tubuh yang akan dianalisa adalah postur tubuh yang dilakukan pekerja dalam waktu yang paling lama, yaitu pada saat pengisian bubuk kopi ke dalam plastik.
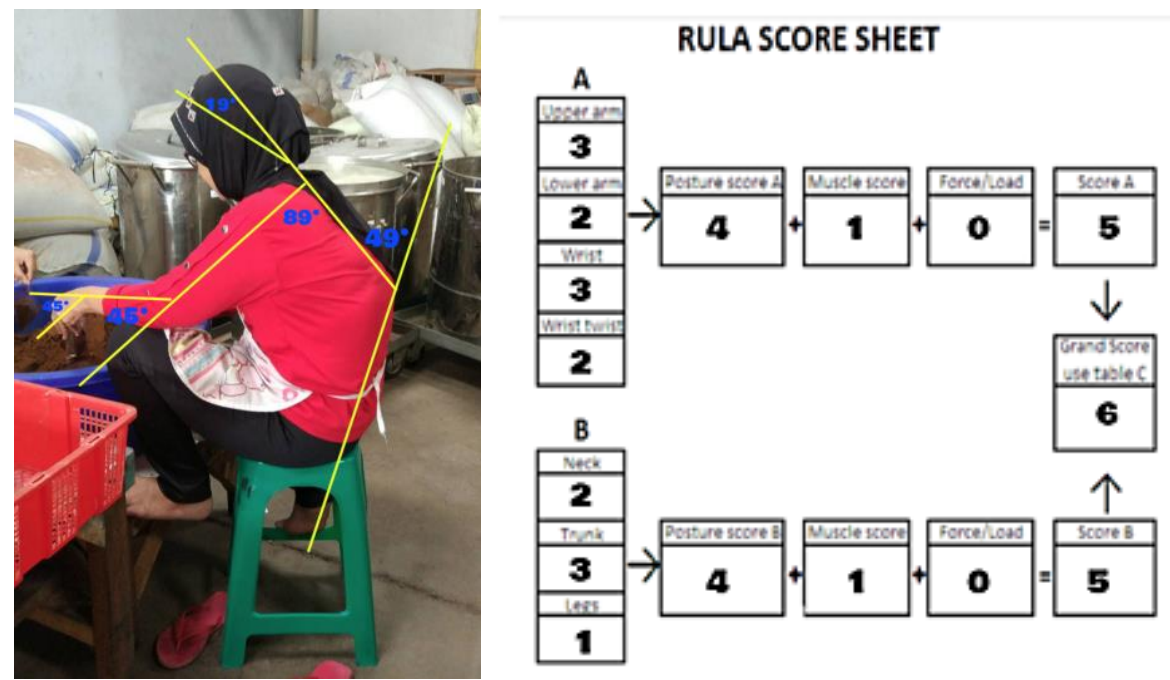

Gambar 8. Analisa Postur dan score sheet Packing 1

Berdasarkan analisa RULA pada postur pekerja packing 1 yang telah dilakukan, postur pekerja tersebut menghasilkan nilai 6. Nilai tersebut menunjukkan bahwa postur tersebut perlu dilakukan investigasi lanjutan dan implementasikan harus dilakukan secepatnya. Pada stasiun kerja ini, pekerja bekerja dengan posisi yang membungkuk pada bagian punggungnya. Hal ini disebabkan oleh beberapa hal, yaitu meja dan kursi yang tidak ergonomis. Bekerja pada posisi ini secara terus-menerus bisa mencederai beberapa bagian tubuh pada pekerja, sehingga dianjurkan untuk mengubah stasiun kerja ini agar lebih ergonomis. 
Solusi perbaikan yang dianjurkan pada stasiun packing 1 ada 3 alternatif, yakni merancang meja yang ergonomis, merancang suatu ember yang memiliki corong dan katup (Gambar 18), dan kotak yang memiliki mekanisme buka tutup (Gambar 19). Saat ini pekerja mengisi bubuk kopi dengan cara yang konvensional, yakni dengan menggunakan sendok. Posisi ember yang berisi bubuk kopi saat ini sangat jauh dengan pekerja, sehingga pekerja perlu membungkukkan badannya untuk bekerja. Penggunaan meja yang lebih ergonomis bisa mengurangi sudut bungkuk badan pekerja. Meja yang lebih ergonomis dirancang agar pekerja bisa memasukkan kakinya ke bagian bawah meja, sehingga lebih mudah menjangkau ember yang berisi bubuk kopi. Alternatif lain dari solusi perbaikan yang diusulkan adalah perancangan sebuah ember yang memiliki corong dan katup atau kotak dengan mekanisme buka tutup. Dengan adanya ember ataupun kotak, pekerja bisa bekerja dengan posisi duduk yang ideal dan memudahkan pekerja dalam melakukan pekerjaannya. Kedua solusi tersebut memanfaatkan tekanan dan sisi miring agar bubuk kopi bisa keluar dengan baik. Penggunaan katup adalah agar bubuk kopi hanya keluar apabila katup terbuka. Kedua solusi tersebut memiliki kelebihan dan kekurangan. Kelebihan dari ember modifikasi adalah menggunakan biaya yang lebih kecil karena pihak perusahaan hanya perlu memodifikasi ember yang saat ini masih digunakan dengan menambahkan corong dan katup, tetapi kekurangannya adalah bubuk kopi tidak bisa keluar dengan maksimal karena bubuk kopi bisa terhambat di sisi bawah dinding ember. Kelebihan dari kotak modifikasi adalah bubuk kopi bisa keluar dengan maksimal, tetapi kekurangannya adalah menggunakan biaya yang relatif tinggi karena perlu membuat kotak dan mekanisme buka tutup katupnya.

Kedua solusi tersebut memiliki konsep penempatan yang berbeda, ember modifikasi perlu ditempatkan pada rangka dengan tinggi yang berbeda (sisi depan lebih pendek daripada sisi belakang) agar permukaan miring dan bubuk kopi bisa keluar, sedangkan tinggi rangka pada kotak modifikasi dibuat dengan tinggi yang sama karena pada bagian dalam kotak sudah terdapat sisi miring. Tinggi dari setiap kaki rangka disesuaikan dengan posisi duduk ideal pekerja. Dengan implementasi salah satu dari ketiga solusi tersebut, pekerja tidak perlu membungkukkan badannya dengan sudut yang besar. Penggunaan kursi yang adjustable dan menambah tempat pijakan kaki bisa membuat pekerja menjadi lebih nyaman.

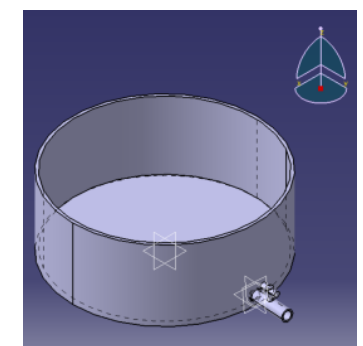

Gambar 9. Ember Modifikasi

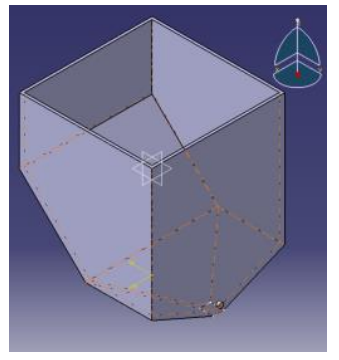

Gambar 10. Kotak Modifikasi

2. Packing 2

Berdasarkan hasil CMDQ, pekerja ini memiliki keluhan rasa sakit di pinggul/bokong, paha, dan kaki bagian bawah. Pekerja ini memiliki pekerjaan dengan postur yang relatif sama setiap saatnya, sehingga postur tubuh yang akan dianalisa adalah postur tubuh yang dilakukan pekerja dalam waktu yang paling lama, yaitu pada saat menimbang bubuk kopi yang sudah terdapat di dalam bungkusan plastik. 

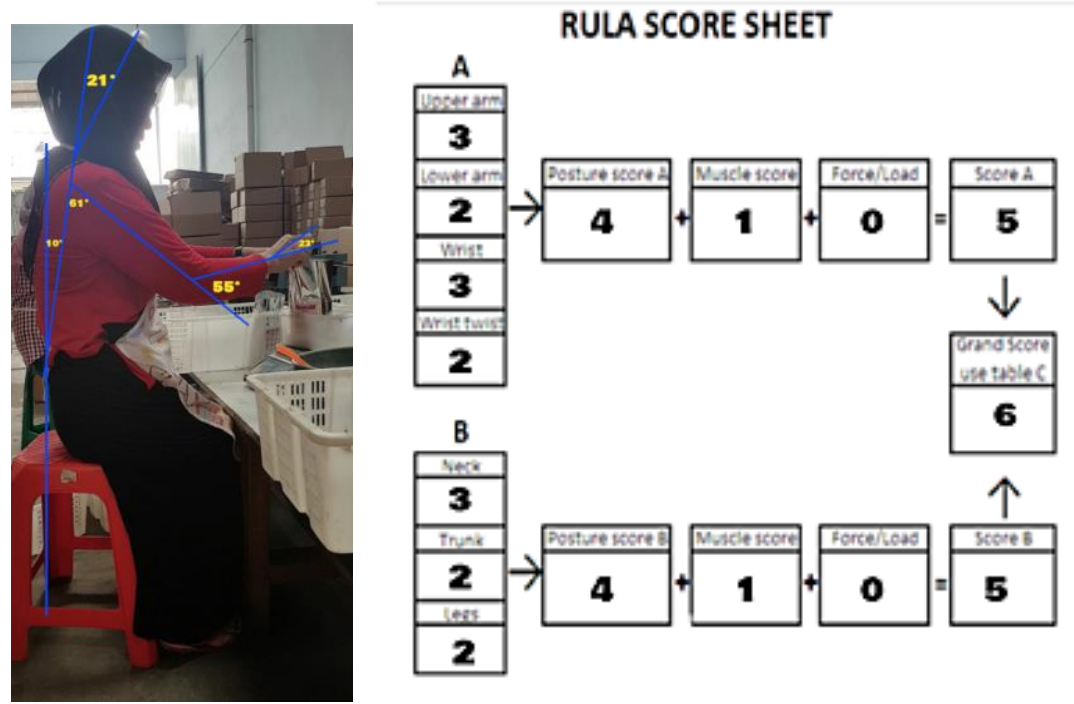

Gambar 11. Analisa Postur dan score sheet Packing 2

Berdasarkan analisa RULA pada postur pekerja packing 2 yang telah dilakukan, postur pekerja tersebut menghasilkan nilai 6. Nilai tersebut menunjukkan bahwa postur tersebut perlu dilakukan investigasi lanjutan dan implementasikan harus dilakukan secepatnya. Pada stasiun kerja ini, pekerja tidak memiliki meja yang ergonomis. Meja pada stasiun ini terlalu rendah, sehingga kaki pekerja tidak bisa dimasukkan ke bagian bawah meja yang membuat pekerja harus bekerja dengan sudut lengan atas yang besar. Selain itu, pekerja juga harus bekerja dengan posisi leher dan badan yang membungkuk yang bisa menyebabkan cedera muskuloskeletal apabila dilakukan dalam jangka waktu yang lama.

Solusi perbaikan yang dianjurkan pada stasiun packing 2 adalah mengganti kursi dan meja yang lebih ergonomis dengan postur tubuh pekerja dan menambah tempat pijakan kaki. Berdasarkan analisis RULA pada stasiun ini, posisi meja yang terlalu rendah membuat pekerja tidak bisa memasukkan kaki ke dalam bagian bawah meja, sehingga lengan atas membentuk sudut yang besar agar pekerja bisa melakukan pekerjaannya. Penggunaan meja dan kursi yang ergonomis bisa mengatasi masalah tersebut. Meja dan kursi yang digunakan harus sesuai dengan antropometri pekerja, sehingga perlu dilakukan penelitian yang lebih lanjut mengenai ukuran-ukuran yang cocok agar pekerja bisa bekerja dengan nyaman. Pekerja juga tidak memiliki tempat pijakan kaki. Tanpa adanya pijakan kaki untuk pekerja, bisa menyebabkan resiko sakit pada kaki dan punggung bawah pekerja, sehingga dianjurkan untuk menambah pijakan kaki agar pekerja bekerja dengan lebih nyaman.

\section{Packing 3}

Berdasarkan hasil CMDQ, pekerja ini memiliki keluhan rasa sakit di punggung bawah. Pekerja ini memiliki pekerjaan dengan postur yang relatif sama setiap saatnya, sehingga postur tubuh yang akan dianalisa adalah postur tubuh yang dilakukan pekerja dalam waktu yang paling lama, yaitu pada saat penggunaan mesin sealing. 

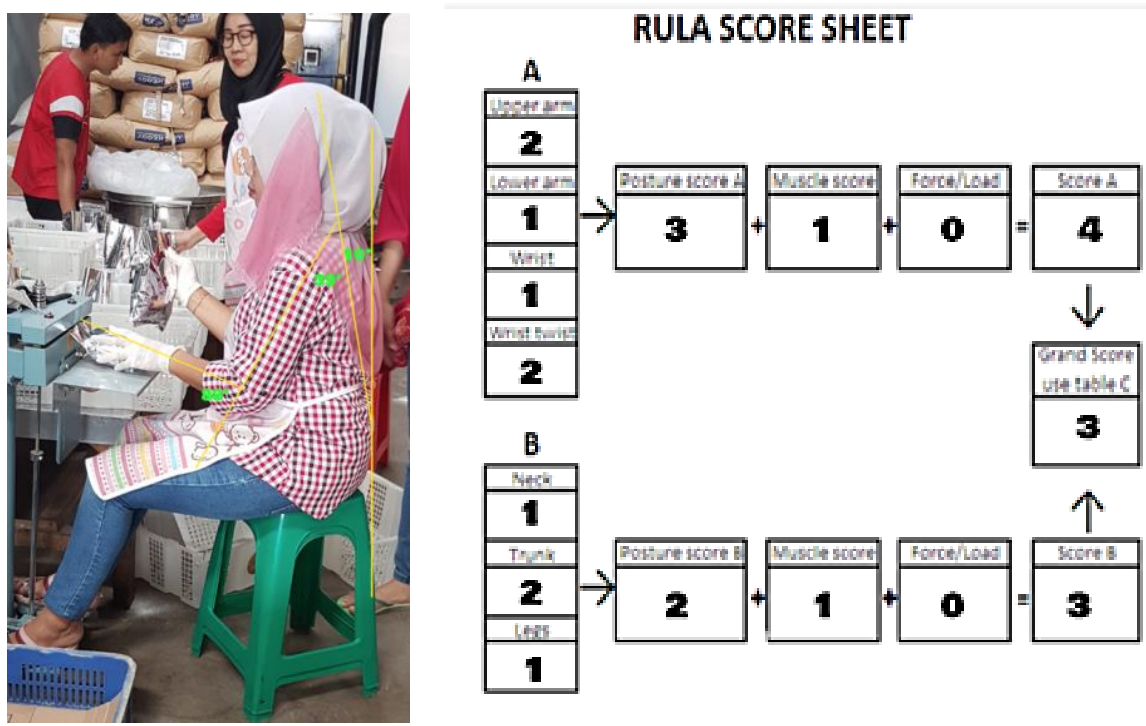

Gambar 12. Analisa Postur dan score sheet Packing 3

Berdasarkan analisa RULA pada postur pekerja packing 2 yang telah dilakukan, postur pekerja tersebut menghasilkan nilai 3. Nilai tersebut menunjukkan bahwa postur tersebut perlu dilakukan investigasi selanjutnya dan mungkin dilakukan perubahan. Pada stasiun kerja ini, pekerja memiliki stasiun kerja yang cukup ergonomis. Pekerja menggunakan alat sealing yang sudah didesain agar ideal dengan tubuh pekerja.

Pekerja pada stasiun ini sudah memiliki tempat kerja yang cukup ergonomis. Tidak ada perbaikan yang bisa dilakukan pada stasiun ini. Berdasarkan analisis RULA yang telah dilakukan, memang terdapat dua bagian tubuh yang butuh diperhatikan, yakni lengan atas dan badan. Agar sudut lengan atas yang terbentuk bisa menjadi lebih kecil, pihak perusahaan bisa mengganti kursi yang saat ini dipakai pekerja menjadi kursi yang adjustable agar pekerja meninggikan tinggi kursi, sehingga pekerja memiliki sudut lengan atas yang ideal. Akan tetapi, penggunaan kursi yang lebih tinggi bisa mengakibatkan hal lain, yakni menambah sudut badan dan leher. Hal itu dikarenakan pekerja perlu membungkukkan badan dan leher untuk melihat bungkusan kopi yang hendak dilakukan sealing.

Secara keseluruhan, ada beberapa perbaikan yang bisa diterapkan ke semua pekerja atau stasiun kerja, yakni sebagai berikut:

1. Melakukan peregangan yang teratur

Para pekerja mengakui bahwa mereka biasanya melakukan peregangan saat mereka bekerja dan sering berolahraga di luar jam kerja. Akan tetapi, pihak perusahaan sebaiknya menyusun suatu program peregangan yang teratur untuk memastikan bahwa pekerja melakukan peregangan dan melakukannya dengan benar. Sebaiknya pekerja melakukan peregangan satu kali sebelum pekerjaan dan satu kali lagi saat jam kerja. Peregangan penting untuk dilakukan karena bisa mengurangi potensi cedera muskuloskeletal pada tubuh pekerja. Peregangan yang dilakukan harus benar, peregangan dengan metode yang tidak benar bisa mencederai tubuh pekerja. Selain itu, peregangan yang dilakukan di jam kerja bisa mengurangi kebosanan yang mungkin timbul pada saat bekerja. Program peregangan tubuh yang disusun sebaiknya menarik agar seluruh pekerja menjadi antusias untuk mengikutinya. Berikut adalah beberapa postur yang bisa dilakukan pada saat melakukan peregangan.

2. Menyediakan kursi yang nyaman untuk digunakan

Sebagian pekerja mengakui bahwa kursi yang digunakan atau tersedia di perusahaan sudah nyaman untuk digunakan, namun terdapat pekerja yang mengakui bahwa kursi yang tersedia tidak nyaman untuk digunakan. Pekerja mengakui bahwa kursi yang tidak nyaman digunakan karena terbuat dari bahan plastik, sehingga panas dan tidak nyaman untuk pinggul apabila digunakan dalam jangka waktu yang lama. Kenyamanan dari kursi yang disediakan bukan 
hanya pada pekerja yang bekerja dalam posisi duduk, tetapi juga pada pekerja yang bekerja pada posisi berdiri. Berdasarkan data frekuensi istirahat pekerja, pekerja yang paling sering beristirahat adalah Bapak L3 yang merupakan pekerja pada posisi berdiri, sehingga kenyamanan kursi untuk istirahat juga harus diperhatikan. Oleh karena itu, pihak perusahaan perlu menyediakan atau mengganti kursi yang saat ini digunakan menjadi kursi yang nyaman untuk semua pekerja.

\section{Kesimpulan dan Saran}

Pekerja pada PT. X memiliki resiko bahaya muskuloskeletal pada pekerjaan yang mereka lakukan. Pada stasiun Roasting, bagian tubuh pekerja pada stasiun ini yang memiliki nilai CMDQ yang relatif tinggi adalah leher, punggung atas, punggung bawah, lutut, dan betis. Analisa dengan metode REBA pada postur kerja pekerja ini menghasilkan nilai 8 yang tergolong dalam kategori resiko bahaya yang tinggi, langkah yang harus dilakukan adalah investigasi dan perubahan harus diimplementasikan. Solusi yang diberikan adalah menggunakan troli adjustable.

Sedangkan pada stasiun Mixing, bagian tubuh pekerja pada stasiun ini yang memiliki nilai CMDQ yang relatif tinggi adalah leher, punggung atas, punggung bawah, lutut, dan betis. Analisa dengan metode REBA pada postur kerja pekerja ini menghasilkan nilai sebesar 9 yang tergolong dalam kategori resiko bahaya yang tinggi, langkah yang harus dilakukan adalah investigasi dan perubahan harus diimplementasikan. Solusi yang diberikan adalah menggunakan kuas yang lebih panjang.

Pada stasiun Grinding, bagian tubuh pekerja pada stasiun ini yang memiliki nilai CMDQ yang relatif tinggi adalah punggung bawah dan betis. Analisa dengan metode REBA pada postur kerja pekerja ini menghasilkan nilai sebesar 7 yang tergolong dalam kategori resiko sedang, langkah yang harus dilakukan adalah investigasi lanjutan dan implementasikan harus dilakukan secepatnya. Solusi yang diberikan adalah menggunakan bantuan troli adjustable, membuat mekanisme penyedotan biji kopi, dan memberikan kursi pada stasiun kerja ini.

Pada stasiun Packing 1, bagian tubuh pekerja pada stasiun ini yang memiliki nilai CMDQ yang relatif tinggi adalah punggung atas dan punggung bawah. Analisa dengan metode RULA pada postur kerja pekerja ini menghasilkan nilai sebesar 6 yang mengindikasikan bahwa pekerjaan ini perlu dilakukan investigasi dan implementasi perubahan harus segera dilakukan. Solusi yang diberikan adalah merancang meja yang ergonomis atau merancang suatu ember yang memiliki corong dan katup atau kotak yang memiliki mekanisme buka tutup.

Pada stasiun Packing 2, bagian tubuh pekerja pada stasiun ini yang memiliki nilai CMDQ yang relatif tinggi adalah pinggul/bokong, paha, dan kaki bagian bawah. Analisa dengan metode RULA pada postur kerja pekerja ini menghasilkan nilai sebesar 6 yang mengindikasikan bahwa pekerjaan ini perlu dilakukan investigasi dan implementasi perubahan harus segera dilakukan. Solusi yang diberikan adalah mengganti kursi dan meja yang lebih ergonomis dengan postur tubuh pekerja dan menambah tempat pijakan kaki.

Sedangkan pada stasiun Packing 3, bagian tubuh pekerja pada stasiun ini yang memiliki nilai CMDQ yang relatif tinggi adalah punggung bawah. Analisa dengan metode RULA pada postur kerja pekerja ini menghasilkan nilai sebesar 3 yang mengindikasikan bahwa pekerjaan ini perlu dilakukan investigasi dan mungkin perlu dilakukan perubahan. Tidak ada solusi perbaikan yang spesifik untuk stasiun ini.

Stasiun Packing 4, bagian tubuh pekerja pada stasiun ini yang memiliki nilai CMDQ yang relatif tinggi adalah punggung bawah, lutut, dan betis. Analisa dengan metode REBA pada postur kerja pekerja ini menghasilkan nilai sebesar 9 yang tergolong dalam kategori resiko bahaya yang tinggi, langkah yang harus dilakukan adalah investigasi dan perubahan harus diimplementasikan. Solusi yang diberikan adalah mengubah metode kerja. 
Secara umum, solusi yang diberikan adalah melakukan peregangan yang teratur, dan menyediakan kursi yang nyaman untuk digunakan.

Penelitian selanjutnya dapat mengkhususkan pada desain alat bantu dari solusi yang ditawarkan dalam penelitian ini.

\section{Daftar Pustaka}

Annisa, R., (20018), Analysis of the Working Position of Sandal Operator Using RULA and REBA Approach at Sisman Corporation (SISCO), International Conference on Science and Technology (ICST 2018), Atlantis Highlights in Engineering (AHE), Vol 1, pp. 684-689.

Canadian Centre for Occupational Health and Safety., (2014), Work-related Musculoskeletal Disorders (WMSDs), https://www.ccohs.ca/oshanswers/diseases/rmirsi.html, Diakses pada hari Kamis, 20 Juni 2019 Pk. 08.00 WIB.

Chiasson, M., Imbeau, D., Major, J., Aubry, K., Delisle, A., (2015), Influence of muculoskeletal pain on workers' ergonomic risk-factor assessments, Applied Ergonomics, Vol. 49, pp. 1-7

Ergonomics Plus. (n.d), The Definition and Causes of Musculoskeletal Disorders, https://ergoplus.com/musculoskeletal-disorders-msd/, Diakses pada hari Senin, 10 Juni 2019 Pk. 18.00 WIB.

Ergonomics Plus. (n.d), A Step-by-Step Guide to the REBA Assessment Tool, https://ergoplus.com/reba-assessment-tool-guide/, Diakses pada hari Kamis, 20 Juni 2019 Pk. 09.00 WIB.

Ergonomics Plus. (n.d), A Step-by-Step Guide to the RULA Assessment Tool, https://ergoplus.com/rula-assessment-tool-guide/, Diakses pada hari Minggu, 23 Juni 2019 Pk. 11.00 WIB.

Hedge, A., (1999), Cornell University Ergonomics Web, CUergo: Musculoskeletal Discomfort Questionnaires, http://ergo.human.cornell.edu/ahmsquest.html, Diakses pada hari Sabtu, 15 Juni 2019 Pk. 12.30 WIB.

McAtammey, Lynn and Corlett E. Nigel, (1993), RULA: a survey method for the investigation of work-related upper limb disorders, Applied Ergonomics, Vol. 24, No. 2, pp.91-99, http://ftp.demec.ufpr.br/disciplinas/TM802/RULA_original\%201993.pdf, Diakses pada hari Kamis, 20 Juni 2019 Pk. 10.00 WIB.

Singh, L P., (2010), Work Posture Assessment in Forcing Industry: An Exploration Study in India, International Journal of Advanced Engineering Technology Vol. I Issue III, pp 358-366.

World Health Organization, (2001), Occupational Health, https://www.who.int/occupational_health/regions/en/oehemhealthcareworkers.pdf, diakses pada hari Kamis, 20 Juni 2019 Pk. 13.00 WIB. 